\title{
Determination of Critically Objects of Electric Power Systems from the Position of Energy Security
}

\author{
Dmitry Krupenev ${ }^{1, *}$ \\ ${ }^{1}$ Melentiev Energy Systems Institute of Siberian Branch of the Russian Academy of Sciences, ESI SB RAS, Irkutsk, Russia
}

\begin{abstract}
The paper deal the problem of definition and ranking of critical objects (CO) in electric power systems (EPS). The identification of the CO is necessary for the timely adoption of measures to organize the provision of the required level of energy security of the region where the object is location. The adequacy model is used for determine the critical objects of EPS, within the framework of which the simulation of the functioning of EPS during the given time interval is carried out, taking into account the main random factors affecting its operation. Approbation of the proposed approach is presented on the interconnected power system.
\end{abstract}

\section{Introduction}

The energy security of Russia and its regions includes two main aspects:

- we need to provide for long-time no-deficit with the required types of energy resources of consumers in the operation of energy in standard conditions;

- we need to create of conditions for provision of energy resources to consumers in emergency situations (ES).

When we considerate of the second aspect we have to define of critical objects (CO) of the fuel and energy complex (FEC), i.e. those facilities, partial or complete failure of which can cause significant damage to the economy of the country. In this case, the reasons for the failure can be different from the effects of natural disasters before terrorist activities.

The CO FEC are objects whose violation or termination of their functioning will lead to a loss of economic management of the Russian Federation, a constituent entity of the Russian Federation or an administrative-territorial unit, its irreversible negative change (destruction) or a significant decrease in the safety of the population [1]. In this paper the problem of determining the $\mathrm{CO}$ focuses on the electric power industry, namely, on the electric power system (EPS).

The definition of the CO FEC should be based on the following main possible negative consequences for society and the economy of the country when it is damaged:

1. Economic consequences: damage to electricity consumers due to short supply and energy companies in case of damage to the power plant, as well as in case of damage to the thermal power plant, damage from shortage of heat energy to consumers.

2. Environmental consequences: possible negative processes on the environment in the event of an accident at the power industry site.
3. Social consequences: the impact of a possible accident on the health and lives of people.

The importance of the object is determined on the basis of a comprehensive evaluation of the submitted criteria. In this paper, the focus is on assessing the economic consequences of accidents at power facilities. Assessment of economic consequences and ranking of electric power facilities on the importance of this indicator will allow making priorities in the al-location of funds for ensuring energy security and the development of the energy system and, thereby, increasing the economic efficiency of the operation of EPS. The identification and ranking of the CO of EPS will allow focusing on selected objects to increase their security against different types of threats, including from terrorist acts (including cyber terrorism).

The definition of the $\mathrm{CO}$ is an important task not only for the electric power industry, there are already approaches to the definition of the $\mathrm{CO}$ in the gas transportation system [2, 3]. In these sources, it is suggested that, based on the analysis of the operation of the transport system, the $\mathrm{CO}$ should be assessed at the most intense gas consumption per day, by determining the resulting gas deficiencies, by disconnecting in turn the elements from the pre-established list.

EPS is a complex technical facility that is fundamental for the successful development of the country's economy. EPS has a number of characteristics related to the definition of $\mathrm{CO}$ :

- there are many states of electricity and power consumption characteristic of different seasons, under these conditions, in determining the $\mathrm{CO}$, it is necessary to analyse the maximum number of states, since the degree of importance of the object can manifest itself not only in the state of maximum power consumption. In different regions the maximum power consumption can be for different months;

\footnotetext{
Corresponding author: krupenev@isem.irk.ru
} 
- we need to take into account the scheduled repairs of power equipment in addition to the consumption regime in determining the $\mathrm{CO}$, since their conduct is mandatory and, in the final analysis, the equipment that is under planned repair will have an additional impact on the possible power shortage and underexposure - power outage upon failure of the analysed object;

- there are some equipment in the EPS that can go out of operation during the calculated period in addition to the failure of the analysed object, and thereby aggravate the current situation.

\section{Statement of the problem of determining and ranking the CO EPS and the methodology for its solution}

We have to use a model that simulates the operation of EPS for a year, and in which all the factors affecting the power shortage and under-supply of the factors stated above for the determination and ranking of EPS CO. The model of estimating the adequacy of EPS is reasonable to take as a basis [4]. In this model based on the Monte Carlo method, many EPS operating modes are simulated over a one-year period, while scheduled repairs, unscheduled repairs, regular and irregular load fluctuations are recorded. The model consists of three computational stages:

1. Stage of formation of design conditions of EPS.

2. Stage of determining the capacity deficits of the generated EPS states. The mathematical formulation of this problem is as follows [5]:

for assessment of the power shortage in the $k$-th power system state, $k=1, \ldots, N$, it is necessary to determine:

$$
\sum_{i=1}^{n}\left(\bar{y}_{i}^{k}-y_{i}\right) \rightarrow \min
$$

subject to the balance constraints

$$
\begin{gathered}
x_{i}-y_{i}+\sum_{j=1}^{n}\left(1-z_{j i} a_{j i}\right) z_{j i}-\sum_{j=1}^{n} z_{i j}=0, i=1, \ldots, n, i \neq j, \\
y_{i} \leq \bar{y}_{i}^{k}, i=1, \ldots, n, \\
x_{i} \leq \bar{x}_{i}^{k}, i=1, \ldots, n, \\
z_{i j} \leq z_{i j}^{-k}, i=1, \ldots, n, j=1, \ldots, n, i \neq j, \\
y_{i} \geq 0, x_{i} \geq 0, z_{i j} \geq 0,
\end{gathered}
$$

where: $x_{i}$ is the usable capacity at node $i, \bar{x}_{i}^{k}$ is the available generating capacity at node $i, y_{i}$ is the served load at node $i, \bar{y}_{i}^{k}$ is the load value at node $i$, $Z_{i j}$ - is the power flow from node $i$ to node $j, \bar{Z}_{i j}^{k}$ is the transfer capability of transmission lines between nodes $i$ and $j, a_{i j}$-are the given positive coefficients of specific power losses at its transmission from node $i$ to node $j$, $i \neq j, i=1, \ldots, n, j=1, \ldots, n, i \neq j, k=1, \ldots, N$.

3. Stage of determining mathematical expectation (m.e.) of undersupply of the electricity to consumers and m.e. of the capacity deficits.

We used this sequence of actions to determine and rank the $\mathrm{CO}$ :

1. Formation of the list of objects of EPS for the definition of m.e. capacity shortage and m.e. of undersupply of the electricity to consumers in the event of their failure. Formation can be carried out in several ways:

- alternate search of power stations and power lines for one object;

- by sequences sort out of expertly assigned objects of EPS.

2. Assessment of the adequacy of all assigned states, depending on the chosen method in the first step. The definition for each variant is m.e. of the capacity deficits and m.e. of undersupply of the electricity to consumers. The assessment can be carried out for any a priori of the appointed time interval: year, month, day, and hour.

3. Ranking of the results. Identifying the objects most strongly affecting m.e. of the capacity deficits and m.e. of undersupply of the electricity to consumers, determination and ranking of the $\mathrm{CO}$ of EPS.

\section{Experimental investigation}

We will show the definition of $\mathrm{CO}$ on the interconnected power system (IPS) of Siberia. IPS of Siberia is a large power association that is part of the Unified Power System of Russia. Large scale thermal and hydraulic power plants operate in the UPS of Siberia, as well as transmission lines (TL) with a voltage of 220 and $500 \mathrm{kV}$. In fig. 1 shows the scheme of the IPS of Siberia [5] and the transformed model of the IPS of Siberia for determining the $\mathrm{CO}$. Clustering in the zones of reliability of the IPS of Siberia was carried out on the basis of the division into the constituent entities of the Russian Federation, the exception is the Bodaibo download center, formally belonging to the Irkutsk region, but actually connected with the Buryatia energy system.

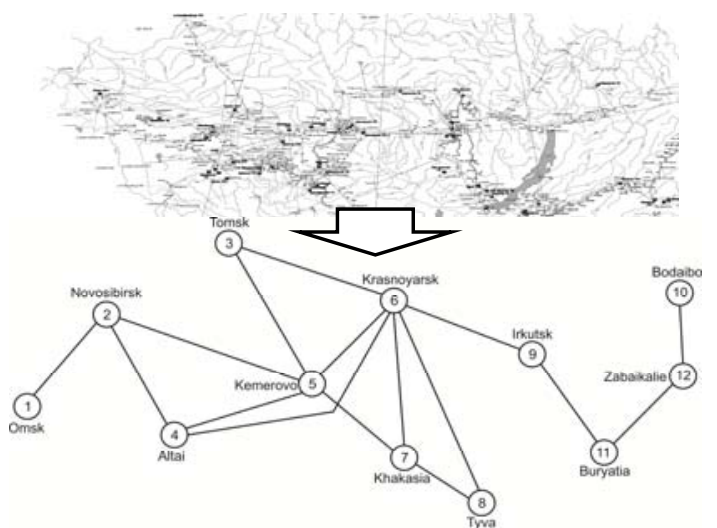

Fig. 1. Model of the IPS of Siberia for the assessment of the CO. 
Table 1 presents the characteristics of the reliability zones of the calculated model of the IPS of Siberia.

Table 1. Characteristics of reliability zones of the IPS of Siberia.

\begin{tabular}{|c|c|c|c|}
\hline $\begin{array}{c}\text { № } \\
\text { zone }\end{array}$ & Zone name & $\begin{array}{c}\text { Annual peak } \\
\text { load, } \\
\text { MW } \\
\end{array}$ & $\begin{array}{c}\text { Available } \\
\text { capacity, } \\
\text { MW } \\
\end{array}$ \\
\hline 1 & Omsk & 1782 & 1479 \\
\hline 2 & Novosibirsk & 2690 & 2730 \\
\hline 3 & Tomsk & 1302 & 918 \\
\hline 4 & Altai & 1884 & 1444 \\
\hline 5 & Kemerovo & 4535 & 4462 \\
\hline 6 & Krasnoyarsk & 6235 & 6848 \\
\hline 7 & Khakasia & 2155 & 5025 \\
\hline 8 & Tyva & 152 & 40 \\
\hline 9 & Irkutsk & 7570 & 9048 \\
\hline 10 & Bodaibo & 90 & 20 \\
\hline 11 & Buryatia & 945 & 898 \\
\hline 12 & Zabaikalie & 1260 & 1156 \\
\hline
\end{tabular}

Table 2 shows the throughput capacity of tie lines connections of the calculation model of the IPS of Siberia.

Table 2. Capacity of tie lines of IPS of Siberia.

\begin{tabular}{|c|c|c|}
\hline $\begin{array}{c}\text { № tie } \\
\text { line }\end{array}$ & Connected zones & $\begin{array}{c}\text { Capability of } \\
\text { tie line, MW }\end{array}$ \\
\hline 1 & $\begin{array}{c}\text { 1. Omsk }-2 . \\
\text { Novosibirsk }\end{array}$ & 1305 \\
\hline 2 & $\begin{array}{c}2 . \text { Novosibirsk }-4 . \\
\text { Altai }\end{array}$ & 1440 \\
\hline 3 & $\begin{array}{c}2 . \text { Novosibirsk }-5 . \\
\text { Kemerovo }\end{array}$ & 1170 \\
\hline 4 & $\begin{array}{c}3 . \text { Tomsk }-5 . \\
\text { Kemerovo }\end{array}$ & 780 \\
\hline 5 & $\begin{array}{c}3 . \text { Tomsk }-6 . \\
\text { Krasnoyarsk }\end{array}$ & \multicolumn{2}{|c|}{} \\
\hline
\end{tabular}

\begin{tabular}{|c|c|c|}
\hline 6 & $\begin{array}{l}\text { 4. Altai - } 5 \text {. } \\
\text { Kemerovo }\end{array}$ & 950 \\
\hline 7 & $\begin{array}{l}\text { 4. Altai }-6 \text {. } \\
\text { Krasnoyarsk }\end{array}$ & 850 \\
\hline 8 & $\begin{array}{l}\text { 5. Kemerovo }-6 . \\
\text { Krasnoyarsk }\end{array}$ & 1560 \\
\hline 9 & $\begin{array}{c}\text { 5. Kemerovo }-7 . \\
\text { Khakass }\end{array}$ & 1650 \\
\hline 10 & $\begin{array}{l}\text { 6. Krasnoyarsk - } \\
\text { 7. Khakass }\end{array}$ & 3400 \\
\hline 11 & $\begin{array}{c}\text { 6. Krasnoyarsk - } \\
\text { 8. Tyva }\end{array}$ & 135 \\
\hline 12 & $\begin{array}{l}\text { 6. Krasnoyarsk - } \\
\text { 9. Irkutsk }\end{array}$ & 3630 \\
\hline 13 & $\begin{array}{l}\text { 7. Khakasia }-8 \text {. } \\
\text { Tyva }\end{array}$ & 135 \\
\hline 14 & $\begin{array}{l}\text { 9. Irkutsk - } 11 \text {. } \\
\text { Buryatia }\end{array}$ & 885 \\
\hline 15 & $\begin{array}{c}\text { 10. } \text { Bodaibo }-11 . \\
\text { Buraytia }\end{array}$ & 66 \\
\hline 16 & $\begin{array}{l}\text { 11. Burayta }-12 . \\
\text { Zabaikalie }\end{array}$ & 410 \\
\hline
\end{tabular}

We need to determine the CO of the IPS of Siberia, at the first stage, we will expertly identify a number of power plants in the reliability zones and TL in tie lines connections, which will be outage off during the research. Reliability zone is a concentrated node, inside of which there are no restrictions on the transmitted power, the most significant contribution to the value of the m.e. of the capacity deficits and m.e. of undersupply of the electricity to consumers will be made by the largest stations in each zone, therefore during the implementation of the experiment at the first stage we will consistently disconnect the largest power stations in each zone.

Table 3. List of power plants to be switched off.

\begin{tabular}{|c|c|c|}
\hline Zone name & $\begin{array}{c}\text { Plant name, } \\
\text { MW }\end{array}$ & $\begin{array}{c}\text { Available } \\
\text { capacity of } \\
\text { plant, } \\
\text { GW }\end{array}$ \\
\hline Omsk & TEP 5 & 0,73 \\
\hline Novosibirsk & TEP 5 & 1,2 \\
\hline Tomsk & AO SHK & 0,43 \\
\hline Altai & Biisk TEP & 0,508 \\
\hline Kemerovo & $\begin{array}{c}\text { Tom-Usinskaia } \\
\text { GDEP }\end{array}$ & 1,34 \\
\hline Krasnoyarsk & $\begin{array}{c}\text { Krasnoyarsk } \\
\text { GEP }\end{array}$ & 5,762 \\
\hline
\end{tabular}




\begin{tabular}{|c|c|c|}
\hline Khakasia & $\begin{array}{c}\text { Sayano- } \\
\text { Shushensk GEP }\end{array}$ & 5,326 \\
\hline Tyva & Kisil TEC & 0,17 \\
\hline Irkutsk & Bratsk GEP & 4,2184 \\
\hline Bodaibo & Mamakan GEP & 0,086 \\
\hline Buryatia & $\begin{array}{c}\text { Gusinoozersk } \\
\text { GDEP }\end{array}$ & 1,16 \\
\hline Zabaikalie & $\begin{array}{c}\text { Haranorsk } \\
\text { GDEP }\end{array}$ & 0,665 \\
\hline
\end{tabular}

Simulation of the operation of the IPS Siberia was carried out during the day corresponding to January 15 . In table 4 shows the results of calculations after disabling the generating objects from table 3 .

Table 4. The effect of outage off power plants in the zones of reliability of the UPS of Siberia.

\begin{tabular}{|c|c|c|c|}
\hline Zone name & $\begin{array}{l}\text { M.e. of } \\
\text { undersuppl } \\
\text { y of the } \\
\text { electricity to } \\
\text { consumers } \\
\text { in the UPS } \\
\text { without } \\
\text { plant } \\
\text { outage, } \\
\text { kWh }\end{array}$ & $\begin{array}{c}\text { M.e. of } \\
\text { under- } \\
\text { supply of } \\
\text { the } \\
\text { electricity } \\
\text { to } \\
\text { consumers } \\
\text { in the UPS } \\
\text { with plant } \\
\text { outage, } \\
\text { kWh } \\
\end{array}$ & $\begin{array}{l}\text { M.e. of } \\
\text { under-supply } \\
\text { of the } \\
\text { electricity to } \\
\text { consumers } \\
\text { reliability } \\
\text { zone, in } \\
\text { which the } \\
\text { stations were } \\
\text { outage, } \mathrm{kWh}\end{array}$ \\
\hline Omsk & 3 & 29 & 0 \\
\hline Novosibirsk & 0 & 30 & 0 \\
\hline Tomsk & 0 & 26 & 0 \\
\hline Altai & 0 & 23 & 0 \\
\hline Kemerovo & 0 & 20 & 0 \\
\hline Krasnoyarsk & 0 & 23 & 0 \\
\hline Khakassia & 0 & 32 & 0 \\
\hline Tuva & 0 & 24 & 0 \\
\hline Irkutsk & 0 & 32 & 0 \\
\hline Bodaibo & 0 & 401 & 358 \\
\hline Buryatia & 0 & 30 & 0 \\
\hline
\end{tabular}

\begin{tabular}{|c|c|c|c|}
\hline Zabaykalsk & 24 & 30 & 27 \\
\hline Sistem & 27 & & \\
\hline
\end{tabular}

We can see in table 4 the current state of the IPS of Siberia from the standpoint of providing electricity consumers to the $\mathrm{CO}$ can only be attributed to the Mamakanskaya GEP in the Bodaibo. In other reliability zones, the withdrawal of the largest power plant from work did not lead to an increase in the under-supply of electricity either in this zone or in the IPS of Siberia, i.e. in the IPS of Siberia there is a sufficient amount of reserve generating capacity to meet the power requirements for the failure of the largest station in each node of the system under consideration.

We made similar outages with electric transmission lines in all link connections of the IPS of Siberia, i.e. we will conduct a series of calculations with the sequential withdrawal of the largest TL in each tie line. Table 5 shows the list of power lines that are switched off during the experiment.

Table 5. List of outage power TL.

\begin{tabular}{|c|c|c|c|}
\hline $\begin{array}{l}\text { № tie } \\
\text { line }\end{array}$ & $\begin{array}{c}\text { Substation of } \\
\text { start TL }\end{array}$ & $\begin{array}{c}\text { Substation } \\
\text { of finish TL }\end{array}$ & $\begin{array}{l}\text { Voltage } \\
\text { TL, kV }\end{array}$ \\
\hline 1 & Tavricheskay & Barabinskay & 500 \\
\hline 2 & Zarya & Altay & 500 \\
\hline 3 & Zarya & Urga & 500 \\
\hline 4 & Tomskaya & $\begin{array}{l}\text { Novo- } \\
\text { Ansherskay } \\
\text { a }\end{array}$ & 500 \\
\hline 5 & Tomskaya & Itatskaya & 500 \\
\hline 6 & Barnaulskaya & $\begin{array}{l}\text { Novokyznet } \\
\text { skaya }\end{array}$ & 500 \\
\hline 7 & Altay & Itatskaya & 500 \\
\hline 8 & $\begin{array}{l}\text { Novo- } \\
\text { Ansherskaya }\end{array}$ & $\begin{array}{l}\text { Nazarovska } \\
\text { ya GREP }\end{array}$ & 500 \\
\hline 9 & $\begin{array}{l}\text { Novokyznetsk } \\
\text { aya }\end{array}$ & $\begin{array}{l}\text { Sayano- } \\
\text { Sushenskay } \\
\text { a GEP }\end{array}$ & 500 \\
\hline 10 & Abakanskaya & Itatskaya & 500 \\
\hline 11 & Ergaki & Turan & 220 \\
\hline 12 & Kamala & Taishet & 500 \\
\hline 13 & Abaza & Ak-Dovurak & 220 \\
\hline
\end{tabular}




\begin{tabular}{|c|l|l|l|}
\hline 14 & Kluchi & $\begin{array}{l}\text { Gusinoozers } \\
\text { kaya GREP }\end{array}$ & 500 \\
\hline 15 & Tacsimo & Mamacan & 220 \\
\hline 16 & $\begin{array}{l}\text { Gusinoozerska } \\
\text { ya GREP }\end{array}$ & $\begin{array}{l}\text { Petrovsk- } \\
\text { Zabaikalsk }\end{array}$ & 220 \\
\hline
\end{tabular}

After carrying out a number of calculations, the values of m.e. of undersupply of the electricity to consumers in the IPS, formed in connection with the disconnection indicated in table. 5 transmission lines. In Table. 6 shows these results.

Table 6. M.e. of undersupply of the electricity to consumers in the IPS of Siberia during the link of power transmission lines in inter-zone communications, $\mathrm{kWh}$ and the ratio to the required electricity generation, \% (the zone numbers correspond to the numbers from the previous tables)

\begin{tabular}{|c|c|c|c|c|c|c|c|c|c|}
\hline $\begin{array}{c}\text { № } \\
\text { zone }\end{array}$ & 2 & 4 & 5 & 6 & 7 & 8 & 9 & 11 & 12 \\
\hline 1 & $\begin{array}{c}302 \\
45\end{array}$ & - & - & - & - & - & - & - & - \\
\hline 2 & - & $\begin{array}{c}29 \\
/ 0\end{array}$ & $\begin{array}{c}32 \\
/ 0\end{array}$ & - & - & - & - & - & - \\
\hline 3 & - & - & $\begin{array}{c}22 \\
/ 0\end{array}$ & $\begin{array}{c}31 \\
/ 0\end{array}$ & - & - & - & - & - \\
\hline 4 & - & - & $\begin{array}{c}40 \\
/ 0\end{array}$ & $\begin{array}{c}46 \\
/ 0\end{array}$ & - & - & - & - & - \\
\hline 5 & - & - & - & $\begin{array}{c}24 \\
/ 0\end{array}$ & $\begin{array}{c}33 \\
/ 0\end{array}$ & - & - & - & - \\
\hline 6 & - & - & - & - & $\begin{array}{c}28 \\
/ 0\end{array}$ & $\begin{array}{c}46 \\
/ 0\end{array}$ & $\begin{array}{c}35 \\
/ 0\end{array}$ & - & - \\
\hline 7 & - & - & - & - & - & $\begin{array}{c}42 \\
/ 0\end{array}$ & - & - & - \\
\hline 9 & - & - & - & - & - & - & - & $\begin{array}{c}47 / \\
0\end{array}$ & - \\
\hline 10 & - & - & - & - & - & - & - & $\begin{array}{c}602 \\
/ 0\end{array}$ & - \\
\hline 11 & - & - & - & - & - & - & - & - & $\begin{array}{c}29 \\
5 / 0\end{array}$ \\
\hline
\end{tabular}

We can see in table 6 expectation of undersupply of the electricity to consumers in the IPS of Siberia has changed slightly, only when the largest TL in the tie line Omsk-Novosibirsk, Bodaibo - Buryatia and Buryat Zabaykalsk was cut off the values assumed large values. With respect to the required generation of electricity that amounts to 663171 million $\mathrm{kWh}$ during the entire disconnection of the above-mentioned power lines, there is no significant change, although locally for the connected reliability zones the above-mentioned power lines can lead to a significant under-release and damage.

Thus, after the analysis of the IPS of Siberia on the subject of $\mathrm{CO}$ from the standpoint of energy security, it was revealed that in the current conditions, the $\mathrm{CO}$ can include: Mamakanskaya GEP and TL $500 \mathrm{kV}$ Tavricheskaya-Barabinskaya; TL 220 Taksimo-Mamakan; TL 220 Gusinoozerskaya GREP - Petrovsk-Zabaikalsk.

\section{Conclusions}

The article considers the problem of determining critical objects in electric power systems. The methodology for determining the CO EPS is proposed. The situation with $\mathrm{CO}$ has been analysed on the example of the IPS of Siberia, it is clarified that in the current conditions of operation of the IPS, Siberia has rather large reserves for both generating facilities and the network part, but several objects are critically important which should be given close attention when planning the development of the IPS of Siberia.

\section{References}

1. On the safety of objects of the fuel and energy complex (Federal Law N 256, 2011)

2. Senderov S.M., Rabchuk V.I., Edelev A.V. Features of the formation of the list of critical objects of the Russian gas transmission network, taking into account the requirements of energy security and possible measures to minimize the negative consequences from emergency situations at such facilities. Izvestiya. Power Engineering, No. 1, (2016)

3. Senderov S., Edelev A. Formation of a List of Critical Facilities in the Gas Transportation System of Russia in Terms of Energy Security. Energy 2017 (2017)

4. Kovalev G.F., Lebedeva L.M. Reliability of power systems. (Novosibirsk: Science, 2015)

5. On the approval of the scheme and program for the development of the Unified Energy System of Russia for 2016-2022 (Order of the Ministry of Energy of Russia No. 147 2016) 